\title{
The identification of environmental parameters which could influence soil bacterial community composition on the Antarctic Peninsula - a statistical approach
}

\author{
C.W. CHONG ${ }^{1}$, D.A. PEARCE ${ }^{2}$, P. CONVEY ${ }^{2}$ and I.K.P. TAN ${ }^{\mathbf{1}}$ \\ ${ }^{I}$ Institute of Biological Sciences, Faculty of Science, University of Malaya, 50603 Kuala Lumpur, Malaysia \\ ${ }^{2}$ British Antarctic Survey, NERC, High Cross, Madingley Road, Cambridge CB3 OET, UK \\ cchhoonngg81@yahoo.com
}

\begin{abstract}
We adopted a statistical approach to identify environmental parameters which might be important in structuring the bacterial community in soils on the Antarctic Peninsula. An assessment of soil bacterial community composition at six environmentally distinct locations was made using terminal restriction fragment length polymorphism (T-RFLP) profiling. All locations are near to Rothera Point, on Reptile Ridge and adjacent islands in Ryder Bay, off the west coast of the Antarctic Peninsula, and were selected to maximize the range of environmental variability easily accessible from Rothera Station. A range of environmental variables was determined, and a Spearman rank correlation test was used to link the community structure and environmental variables. We demonstrated that the taxonomic distribution of the soil bacteria among the six study sites was relatively even, especially among the islands within Ryder Bay, although each location possessed a distinct community structure. Significant differences in the environmental conditions and soil chemical parameters allowed us to identify differences in location and soil $\mathrm{pH}$ as the environmental variables that could most probably explain the soil bacterial community patterns. This observation is consistent with an increasing number of studies from both Arctic and Antarctic locations, and will contribute to the design of future parameter-specific studies to test the potential functional significance of $\mathrm{pH}$ to the Antarctic soil bacterial community.
\end{abstract}

Received 7 July 2011, accepted 26 October 2011, first published online 9 February 2012

Key words: altitude, bacterial diversity, cloning, geographical proximity, $\mathrm{pH}$, T-RFLP

\section{Introduction}

Environmental variation has long been identified as an important determinant of bacterial community structure in soils. This is especially true for Antarctic terrestrial environments where geographical isolation and environmental pressures, such as extreme cold and xeric stress, have led to an apparent impoverishment of soil bacterial diversity in comparison with typical tropical or temperate soil systems (Aislabie et al. 2008). To date, it has been suggested that environmental factors such as geographical proximity, and chemical properties including water, phosphorus, $\mathrm{pH}$, salinity and heavy metal content might account for differences in soil community composition in various Antarctic soils. Further, variation in soil chemical parameters can also co-vary with the lithology (parent rock composition) pedology (silt, sand, clay composition), position (direction, altitude, proximity to water bodies etc.) and the soil microclimate of the investigated location (Yergeau et al. 2007, Aislabie et al. 2008, Cannone et al. 2008b, Chong et al. 2009a, 2010, Pointing et al. 2010). However, current knowledge of how environmental variability might influence soil bacterial community patterns in Antarctica remains extremely limited, and the spatial coverage of bacterial diversity studies remains low across Antarctica (Tindall 2004).

Within Antarctic terrestrial environments, three biogeographical zones are currently recognized: the subAntarctic, Maritime Antarctic and continental Antarctic. The Maritime Antarctic includes the Scotia Arc archipelagos of the South Sandwich, South Orkney and South Shetland islands and the majority of the Antarctic Peninsula southwards to Alexander Island. Mean air temperatures in this zone are below freezing for most of the year, but periodically exceed $0^{\circ} \mathrm{C}$ during summer months (Convey 2003). Along the coastline and associated low lying islands, a high level of marine bird and mammal influence is often observed. This provides an external source of nutrient input which promotes the development of cryptogamic vegetation locally (Bokhorst et al. 2007). Over the last two decades, a number of soil bacterial studies had been carried out in the Maritime Antarctic. However, a majority of the currently available molecular studies have been focused on more northerly locations of the Scotia Arc such as South Georgia $\left(54.15^{\circ} \mathrm{S}, 36.30^{\circ} \mathrm{W}\right)$, Signy Island $\left(60.43^{\circ} \mathrm{S}, 45.38^{\circ} \mathrm{W}\right)$, King George Island $\left(62.11^{\circ} \mathrm{S}, 58.56^{\circ} \mathrm{W}\right)$, and Livingston Island $\left(62.38^{\circ} \mathrm{S}, 60.21^{\circ} \mathrm{W}\right)$ (Yergeau et al. 2007, Chong et al. 2009a, 2010, Foong et al. 2010, Ganzert et al. 2011). 
Table I. GPS position, altitude and soil chemical parameters of the locations studied on Reptile Ridge and Ryder Bay, Antarctic Peninsula. The reported soil chemical parameters at each site were mean values obtained from six replicates.

\begin{tabular}{|c|c|c|c|c|c|c|}
\hline & $\begin{array}{l}\text { 'Iron col' } \\
(\text { IC })^{\mathrm{a}}\end{array}$ & $\begin{array}{l}\text { Ammo Col } \\
(\mathrm{AC})^{\mathrm{a}}\end{array}$ & $\begin{array}{l}\text { Killingbeck Island } \\
\qquad(\mathrm{KB})^{\mathrm{b}}\end{array}$ & $\begin{array}{l}\text { Lagoon Island } \\
\text { (LI) }^{\text {b }}\end{array}$ & $\begin{array}{c}\text { Anchorage Island } \\
\text { (AI) }^{\mathrm{b}}\end{array}$ & $\begin{array}{l}\text { Rothera Point } \\
\text { (RO) })^{\mathrm{b}}\end{array}$ \\
\hline GPS & $\begin{array}{l}67^{\circ} 32.88^{\prime} \mathrm{S} \\
68^{\circ} 09.99^{\prime} \mathrm{W}\end{array}$ & $\begin{array}{l}67^{\circ} 33.27^{\prime} \mathrm{S} \\
68^{\circ} 09.32^{\prime} \mathrm{W}\end{array}$ & $\begin{array}{l}67^{\circ} 34.25^{\prime} \mathrm{S} \\
68^{\circ} 04.20^{\prime} \mathrm{W}\end{array}$ & $\begin{array}{l}67^{\circ} 35.47^{\prime} \mathrm{S} \\
68^{\circ} 14.75^{\prime} \mathrm{W}\end{array}$ & $\begin{array}{l}67^{\circ} 36.18^{\prime} \mathrm{S} \\
68^{\circ} 12.55^{\prime} \mathrm{W}\end{array}$ & $\begin{array}{l}67^{\circ} 34.24^{\prime} \mathrm{S} \\
68^{\circ} 07.66^{\prime} \mathrm{W}\end{array}$ \\
\hline Altitude (m) & 200 & 240 & 27.8 & 13.4 & 10.4 & 4 \\
\hline$\%$ Water & $8.01^{\mathrm{p}}$ & $13.17^{\mathrm{q}}$ & $35.79^{\mathrm{r}}$ & $28.50^{\mathrm{s}}$ & $5.89^{\mathrm{p}, \mathrm{q}}$ & $8.10^{\mathrm{p}, \mathrm{q}}$ \\
\hline $\mathrm{pH}$ & $2.93^{p}$ & $4.57^{\mathrm{q}}$ & $4.80^{\mathrm{q}}$ & $4.78^{\mathrm{q}}$ & $6.41^{\mathrm{r}}$ & $8.17^{\mathrm{s}}$ \\
\hline $\mathrm{EC}\left(\mu \mathrm{S} \mathrm{cm}{ }^{-1}\right)$ & $80.6^{\mathrm{p}}$ & $13.57^{\mathrm{p}}$ & $507.83^{\mathrm{q}}$ & $233.32^{\mathrm{r}}$ & $43.07^{\mathrm{q}}$ & $50.7^{\mathrm{q}}$ \\
\hline$\%$ Nitrogen ${ }^{c}$ & $<0.5$ & $<0.5$ & 1.40 & 0.81 & $<0.5$ & $<0.5$ \\
\hline $\mathrm{Cu}\left(\mathrm{mg} \mathrm{kg}^{-1}\right)$ & $6.62^{\mathrm{p}}$ & $8.10^{\mathrm{p}}$ & $20.36^{\mathrm{p}}$ & $66.87^{p}$ & $6.59^{\mathrm{p}}$ & $81.99^{p}$ \\
\hline $\mathrm{Pb}\left(\mathrm{mg} \mathrm{kg}^{-1}\right)$ & $4.00^{\mathrm{p}}$ & $8.22^{\mathrm{p}}$ & $27.95^{\mathrm{q}}$ & $17.82^{\mathrm{r}}$ & $5.79^{\mathrm{p}}$ & $21.34^{\mathrm{r}}$ \\
\hline $\mathrm{Ni}\left(\mathrm{mg} \mathrm{kg}^{-1}\right)$ & 1.37 & 1.43 & 8.12 & 3.96 & 1.58 & N.D. \\
\hline $\mathrm{Fe}\left(\mathrm{mg} \mathrm{kg}^{-1}\right)$ & $7447.47^{p}$ & $399.86^{\mathrm{q}}$ & $17613.88^{\mathrm{r}}$ & $22945.7^{\mathrm{s}}$ & $5871.03^{\mathrm{p}, \mathrm{t}}$ & $2458.7^{\mathrm{p}, \mathrm{t}}$ \\
\hline $\mathrm{Zn}\left(\mathrm{mg} \mathrm{kg}^{-1}\right)$ & $10.15^{\mathrm{p}}$ & $6.25^{\mathrm{p}}$ & $727.21^{\mathrm{q}}$ & $530.61^{\mathrm{r}}$ & $7.71^{\mathrm{p}}$ & $136.28^{p}$ \\
\hline
\end{tabular}

${ }^{a}$ Reptile Ridge

${ }^{\mathrm{b}}$ Ryder Bay

${ }^{\mathrm{c}}$ The value of $<0.5$ refers to readings below detection limit. The range of $\% \mathrm{C}, \% \mathrm{H}$ and $\% \mathrm{~N}$ reported here represents the smallest and largest values of the detected readings. For example, the $\% \mathrm{C}$ reading for the six replicates at $\mathrm{AC}$ are $<0.5,<0.5,<0.5,<0.5,<0.5,0.83$ while the $\% \mathrm{C}$ for the six replicates at $\mathrm{AI}$ are $<0.5,<0.5,0.51,0.77,0.97,2.16$ respectively.

p, q, r, s, t Significant differences among mean values. Sites with different letters are significantly different $(P<0.05)$.

Despite this overall lack of data, Cary et al. (2010) suggested that soil bacterial community structures in the Antarctic Peninsula might be distinct from those of the McMurdo Dry Valleys in the continental Antarctic, as several discrepancies in phylum-level bacterial community composition between the two regions were observed.

In this study, we assessed the soil bacterial community patterns of six environmentally distinct locations in Ryder Bay and on Reptile Ridge, Adelaide Island, Antarctic Peninsula. The six sites were selected to maximize the environmental heterogeneity available within the area accessible from Rothera Station, and to represent major soil ecosystem types typical of the Antarctic Peninsula region. For instance, nutrient rich soil from Killingbeck Island (KB), Anchorage Island (AI) and Lagoon Island (LI), subject to varying levels of vertebrate influence, represent a common habitat found on most of the low lying islands and coast of the Antarctic Peninsula. Mineral soil from Rothera Point (RO) represents typical barren fellfield locations, while the soil from 'Iron col' (IC) and Ammo $\mathrm{Col}$ (AC) represent dry and nutrient poor soils commonly found in higher altitude regions of the Antarctic Peninsula. To our knowledge, this study is the first molecular assessment of the soil bacterial community composition across the range of environments available near to Adelaide Island (with the exception of Anchorage Island, which was included in the latitudinal transect in Yergeau et al. (2007)). We further evaluate the possibility of delineating soil bacterial community patterns based on differences in the measured physico-chemical soil parameters by adopting a statistical approach. The correlation of terminal restriction fragment length polymorphism (T-RFLP) patterns (as a proxy for bacterial community structure) with environmental variability may provide a better basis for future experimental design to understand the dynamic interactions between environmental gradients and bacterial composition in Antarctica.

\section{Materials and methods}

Sampling sites and sample collection

Soil samples were collected from Ryder Bay and Reptile Ridge off the west coast of the Antarctic Peninsula (Table I, Fig. 1). The former consisted of samples collected from four low altitude islands in Ryder Bay, off south-west Adelaide Island, which are characterized by considerable vertebrate or marine aerosol influence (Convey \& Smith 1997, Bokhorst et al. 2007). The latter were situated on a narrow mountain ridge undulating between c. 250 and $432 \mathrm{~m}$ a.s.l. and relatively free of vegetation other than lichens. All six locations were situated within a $6 \mathrm{~km}$ radius of Rothera Station. General information on the geological and biological features of the sample collection sites is given by Convey \& Smith (1997) and Seymour et al. (2007). In general, sparse development of mosses (dominated by Bryum spp.) and lichens (Usnea spp.) can be observed on moist soil on Reptile Ridge, Killingbeck Island and Rothera Point. Relatively more developed moss stands (composed of Sanionia uncinata (Hedw.) Loeske, Andreaea spp., Brachythecium austrosalebrosum (C. Muell.) Kindb. and Polytrichum alpinum Hedw.) and lichen fellfield 

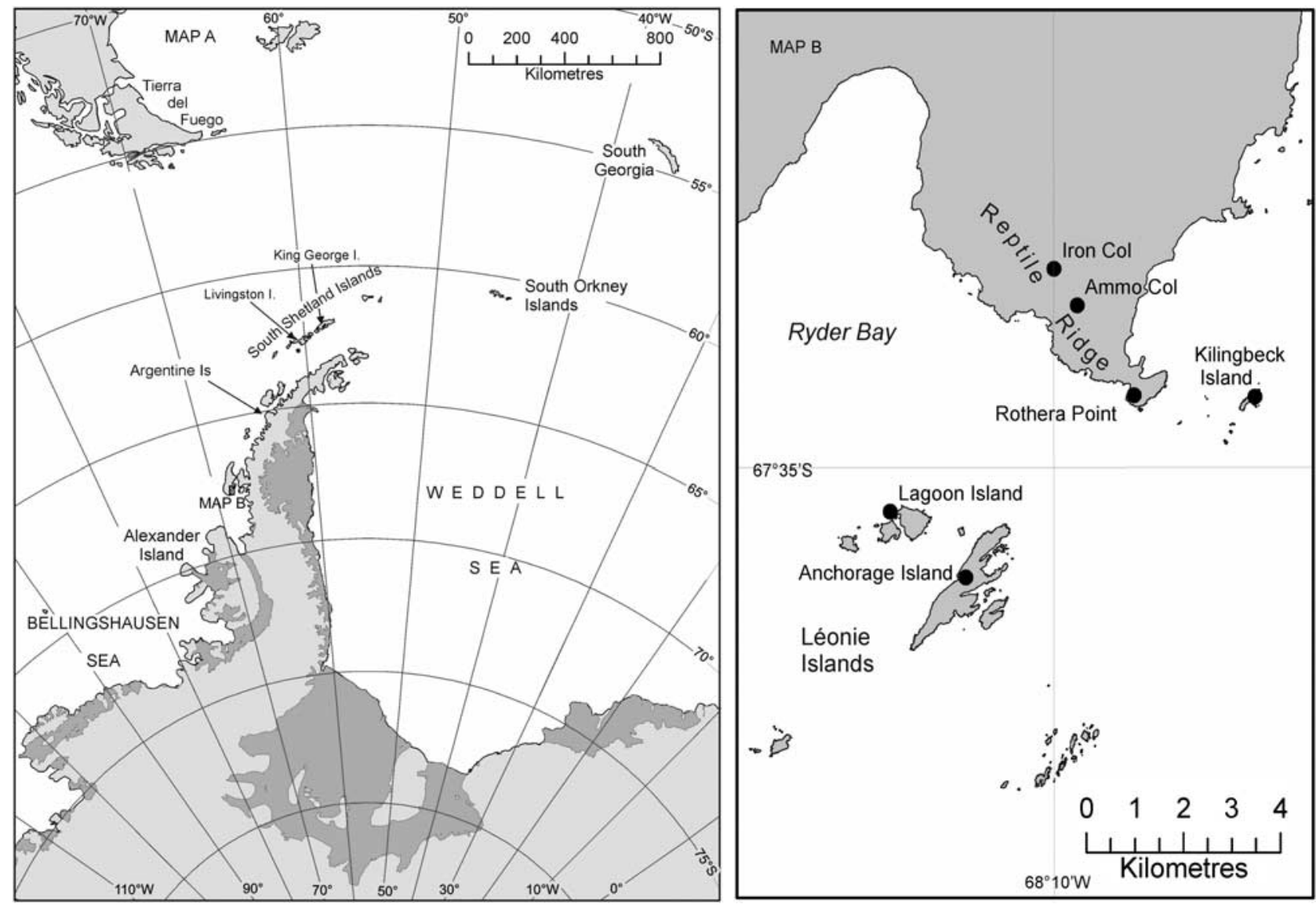

Fig. 1. Map showing the sampling locations of the six studied sites.

(e.g. Umbilicaria decussate (Vill.) Zahlbr., Usnea spp.) are found on Lagoon Island and Anchorage Island. Additionally, small patches of the grass Deschampsia antarctica Desv. can also be found on these two islands. Recent studies from polar environments suggest that the differences in the type of vegetation cover might have minimal impact on the underlying bacterial diversity (Männistö et al. 2007, Teixeira et al. 2010).

At each location, six replicate soil samples (from surface to a depth of $c .5 \mathrm{~cm}$ ) of $c .50 \mathrm{~g}$ were collected using sterile falcon tubes from barren soil at locations with no visible vegetation being present in the sampling plot. The soil samples were kept at $4^{\circ} \mathrm{C}$ prior to soil DNA extraction at the British Antarctic Survey's Rothera Station (within $24 \mathrm{~h}$ of collection) and then frozen $\left(-20^{\circ} \mathrm{C}\right)$.

\section{DNA extraction and soil chemical analyses}

DNA extractions were carried out using UltraClean ${ }^{\mathrm{TM}}$ Power Soil DNA Isolation Kit (MoBio Inc, USA), and the soil chemical (carbon, hydrogen, nitrogen and heavy metals including $\mathrm{Fe}, \mathrm{Cu}, \mathrm{Zn}, \mathrm{Ni}$, and $\mathrm{Pb}$ ) contents and properties (water content, $\mathrm{pH}$, and salinity) were measured as described in Chong et al. (2010). Differences in soil chemical properties between locations were examined using univariate and multivariate analyses of variance (ANOVA/MANOVA) in Statistica 7.0 (StatSoft Inc, USA).

\section{T-RFLP analysis}

Template DNA from each replicate soil sample (six per site) was amplified using the bacteria specific $16 \mathrm{~S}$ primers, 27F (5'-AGA GTT TGA TCM TGG CTC AG-3') and 1492R (5'-TAC GGY TAC CTT GTT ACG ACT T-3) with phosphoramidite fluorochrome 5-carboxyfluorescein attached at the $5^{\prime}$ end to produce amplicons of $c .1500 \mathrm{bp}$. The $50 \mu \mathrm{L}$ reaction mixture contained $1 \mu \mathrm{L}$ of DNA template $(50 \mathrm{x}$ dilution of extracted DNA), $0.5 \mu \mathrm{M}$ of each primer, $0.25 \mathrm{mM}$ of each dNTP, $1 \mathrm{x}$ Taq polymerase buffer $(200 \mathrm{mM}$ Tris- $\mathrm{HCl}$ $(\mathrm{pH} 8.4), 500 \mathrm{mM} \mathrm{KCl})$ and $1 \mathrm{U}$ Taq DNA Polymerase (Invitrogen, USA). The amplification was carried out under the following thermo-cycling profile: $95^{\circ} \mathrm{C}$ for $3 \mathrm{~min} ; 30$ cycles of denaturing at $94^{\circ} \mathrm{C}$ for $30 \mathrm{sec}$, annealing at $52.5^{\circ} \mathrm{C}$ for $30 \mathrm{sec}$, extension at $72^{\circ} \mathrm{C}$ for $1.5 \mathrm{~min}$ with increment of $1 \mathrm{sec}$ in every cycle; and final extension at $72^{\circ} \mathrm{C}$ for $10 \mathrm{~min}$. The amplified DNA was then purified with PCRquick-spin ${ }^{\mathrm{TM}}$ PCR Product Purification Kit (iNtRON Biotechnology, Korea) and digested with MSP-I (Fermentas, USA). Electrophoretic separation of 
restriction fragments was conducted by FirstBase Laboratories (Selangor, Malaysia) using ABI 3100 and ABI 3730XL genetic analysers (Applied Biosystems, USA), with ROXlabelled GeneScan 500 control as a size standard (Applied Biosystems, USA). The scoring of terminal restriction fragments (T-RFs) was carried out using the web-based programme T-Rex (Culman et al. 2009). In order to distinguish true peaks from noise, the T-RFs which showed a peak height lower than 100 units or peak area lower than overall standard deviation were removed. The peak alignment was carried out using the method suggested by Smith et al. (2005). In brief, the peak with the smallest size (bp) across all 36 profiles $(6 \times 6)$ was identified and marked. Peaks within the range of $0.8 \mathrm{bp}$ were then identified and binned into a T-RF. The next smallest peak size across all samples not falling into the first T-RF, but within $0.8 \mathrm{bp}$ range was binned into a second T-RF. This process was continued until all peaks were binned into T-RFs. We chose $0.8 \mathrm{bp}$ as our peak clustering threshold as a smaller value was not able to separate all peaks into different integers.

\section{Statistical analyses of the T-RFLP derived community patterns}

The bacterial species-richness was estimated using both qualitative and semi-quantitative approaches. For qualitative analysis, the bacterial richness was estimated as the number of detected peaks, while the Shannon diversity index weighted using relative peak height of the individual T-RFLP profiles was used to give a semi-quantitative estimate.

For comparison between soil bacterial community compositions, the assemblage patterns were illustrated using principal co-ordinate ordination (PCO). Further, the presence of significant spatial clustering was detected using permutational analysis of variance (PERMANOVA), while the variation between the replicates at each site was compared using the multivariate dispersion index (MVDISP) (Anderson et al. 2008).

Spearman rank correlation (RELATE and BEST routine) was carried out to identify environmental factors (i.e. geographical distance, altitude, and measured soil chemical variables) which showed highest influence on the observed bacterial community patterns. In addition, LINKTREE analysis was performed to separate bacterial communities based on the differences in the highest correlated factors (Clarke et al. 2008). For clarity, The LINKTREE routine compares the differences in the selected variables to the resemblance matrix obtained from the T-RFLP data. The samples are first treated as one group, and subdivided according to the variables that maximized the between cluster variance. The degree of separation is indicated by $\mathrm{B} \%$, the higher the $\mathrm{B} \%$, the higher the variance between the separations, hence representing higher influence on the variation in bacterial community than those with lower $\mathrm{B} \%$.
All PERMANOVA, MVDISP, PCO, RELATE, BEST and LINKTREE routines were carried out using the PERMANOVA + add-on of the PRIMER6 multivariate data analysis package (Plymouth Marine Laboratory, UK).

\section{Cloning, sequencing and phylogenetic analysis}

Polymerase chain reaction (PCR) amplification was carried out on each replicate using primers $27 \mathrm{~F}$ and $1492 \mathrm{R}$, under the same PCR conditions as described above for the T-RFLP analysis. One clone library was created for each site by pooling the PCR amplicons from the replicates into one tube. The pooled DNA was then purified using PCRquick-spin ${ }^{\mathrm{TM}}$ PCR Product Purification Kit (iNtRON Biotechnology, Korea), followed by ligation using pGEM $^{\circledR}-\mathrm{T}$ Easy Vector System (Promega, USA) and transformation into one shot ${ }^{\mathbb{R}}$ TOP10 E. coli (Invitrogen, USA).

Overall, 576 clones were picked based on blue-white selection. The restriction fragment length polymorphism (RFLP) with restriction enzyme Msp-1 (Fermentas, USA) revealed 157 unique RFLP patterns. In order to assess the 16S rRNA gene variation among each of the RFLP patterns, ten pairs of clones with identical RFLP patterns were initially sequenced. They were found to show $>97 \%$ sequence similarity and thus only one or two representatives from each RFLP pattern were sequenced subsequently. The bidirectional sequencing using primers $\mathrm{T} \mathrm{T} 7$ promoter (5'-TAA TAC GAC TCA CTA TAG GG-3') and SP6 (5'-ATT TAG GTG ACA CTA TAG-3') was carried out by FirstBase Laboratories (Selangor, Malaysia).

The DNA sequences were manually checked to identify low quality fragments requiring re-sequencing or removal, before being assembled into contigs. Possible chimeric sequences were screened using the Mallard (Ashelford et al. 2006) and Pintail (Ashelford et al. 2005) programs. Sequences which proved to be chimeric in both programs were excluded from further analysis and the remaining sequences were grouped into operational taxonomic units (OTUs) or ribotypes at a resolution of $97 \%$ sequence homology using Mothur 1.11.0 (Schloss et al. 2009). Using this cut-off, a total of 120 ribotypes was obtained. The ribotypes were then compared with the GenBank database through a BLAST-search, and taxonomic assignments made using the RDP classifier tool. Sequences were submitted to the EMBL database under accession numbers FN811189, FN811206, FN811237 and FR749710-FR749826.

\section{Results and discussion}

\section{Soil chemical parameters}

Soil samples from Ryder Bay (AI, LI, KB and RO) were relatively nutrient rich as compared to Reptile Ridge (AC and IC) (Table I). Due to lower altitude and close proximity to the coastline, the former received high nutrient input 
from the local marine vertebrate population. For example, highest carbon and nitrogen contents were detected from $\mathrm{LI}$ and $\mathrm{KB}$, where the sampling sites were situated close to an elephant seal wallow (Mirounga leonine (L.)) and blueeyed shag (Phalacrocorax atriceps bransfieldensis Murphy, 1936) colony, respectively. Additionally, high carbon content was observed at the sampling site at AI which was located below a rocky ridge $(30-40 \mathrm{~m}$ a.s.1.) that supported approximately 30 south polar skua (Catharacta maccormicki Saunders) nests.

Given the absence of terrestrial vertebrates and reduced development of vegetation, external input from marine animals and the marine environment has been recognized as an important source of nutrients in the Maritime Antarctic region (Bokhorst et al. 2007). Vertebrate faeces/guano deposits may also have contributed to the high water holding capacity, with high water and heavy metal content recorded in soils at KB and LI. As reported previously, heavy metals can be bio-accumulated via the food chain (Nygård et al. 2001) and the deposition of animal faeces can result in elevated levels of metals in the soil (Chong et al. 2009a, 2010).

In general, the soil $\mathrm{pH}$ at sites in Ryder Bay, with the exception of $\mathrm{RO}$, was slightly acidic $(\mathrm{pH} \sim 4.8-6.4)$. This might be due to the presence of nitric acid and sulphuric acid from the natural mineralization of guano and faeces. Conversely, located close to Rothera Station, the soil from RO was slightly alkaline and characterized by elevated $\mathrm{Zn}$, $\mathrm{Pb}$ and $\mathrm{Cu}$ content. High levels of heavy metals have been detected frequently in the soil collected in the vicinity of Antarctic research stations, and have been regarded as a reflection of anthropogenic impact at these locations (Santos et al. 2005, Chong et al. 2009b). In contrast, mineral soils from Reptile Ridge were nutrient poor, acidic ( $\mathrm{pH} \sim 3-4.5)$ and exhibited lower heavy metal content than those of Ryder Bay. The low $\mathrm{pH}$ values may be due to the prevalence of acidic igneous rocks such as rhyolites (Griffiths \& Oglethorpe 1998).

The electrical conductivity (EC) values measured from each study site were highly correlated with the measured percentage of $\mathrm{NaCl}$ (Pearson $R=0.995$ ), possibly suggesting that the conductivity was mainly sourced from marine salts.

When all measured soil chemical properties were considered together (except $\% \mathrm{C}, \% \mathrm{~N}$ and $\mathrm{N}$ - these three parameters were excluded as they showed undetectable or detectable but unmeasurable signals), the Euclidean distance based pairwise PERMANOVA suggested that all sites were significantly different from each other $(P<0.05)$, except IC and AI $(P=0.132)$ which shared similar levels of $\mathrm{Cu}, \mathrm{Pb}$ and $\mathrm{Ni}$. The variability in the underlying soil chemical properties between locations provided a basis to compare the influences of the environmental heterogeneity on the soil bacterial community structures of the studied locations.
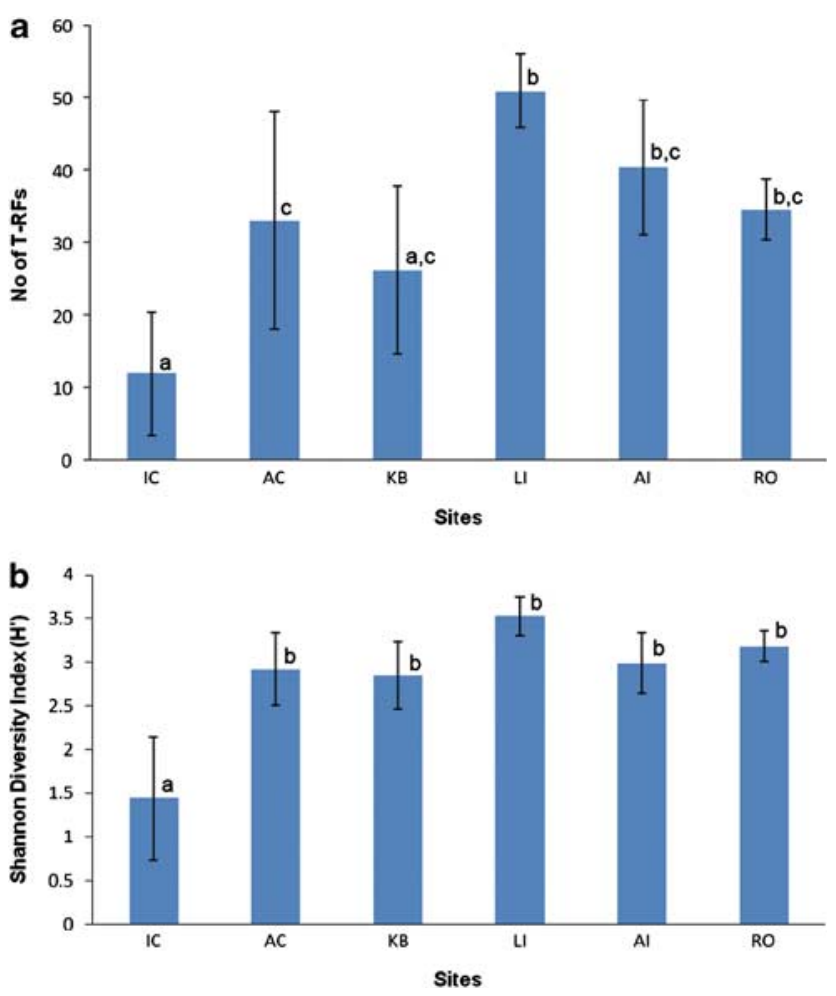

Fig. 2. Soil bacterial richness inferred from terminal restriction fragment length polymorphism (T-RFLP) profiles. a. Average number of T-RFs. b. Shannon diversity index. Sites with different letter are significantly different at $P<0.05$.

\section{Bacterial community patterns from T-RFLP}

In order to assess differences between community membership (occurrence) and composition (relative abundance), interpretation of the T-RFLP derived patterns was carried out using both absence/presence, and the proportional peak height of the T-RFs. From the six sites (six replicates per site), 194 unique T-RF lengths were detected. No apparent differences between community membership or composition were observed. For instance, when considering absence/presence of T-RF peaks, IC showed the lowest number of peaks while LI contained the highest number (Fig. 2a). The same result was obtained when comparison was made using the Shannon diversity index (H'), which takes into account the proportional abundance of each peak (weighted by T-RF peak height) (Fig. 2b). The low bacterial species-richness in IC might be related to its soil $\mathrm{pH}$ value (mean $\mathrm{pH}=2.93$ ), as bacterial diversity has been found to be negatively correlated with increased acidity in soil (Hartman et al. 2008).

By quantifying the MVDISP at each site using both absence/presence and proportional peak height of T-RFs (Table S1, www.journals.cambridge.org/jid_ANS), replicates from $\mathrm{KB}, \mathrm{AC}, \mathrm{RO}$ and $\mathrm{AI}$ were found to register similar levels of variation in community membership and composition. In contrast, the replicates from LI showed a similar number of 


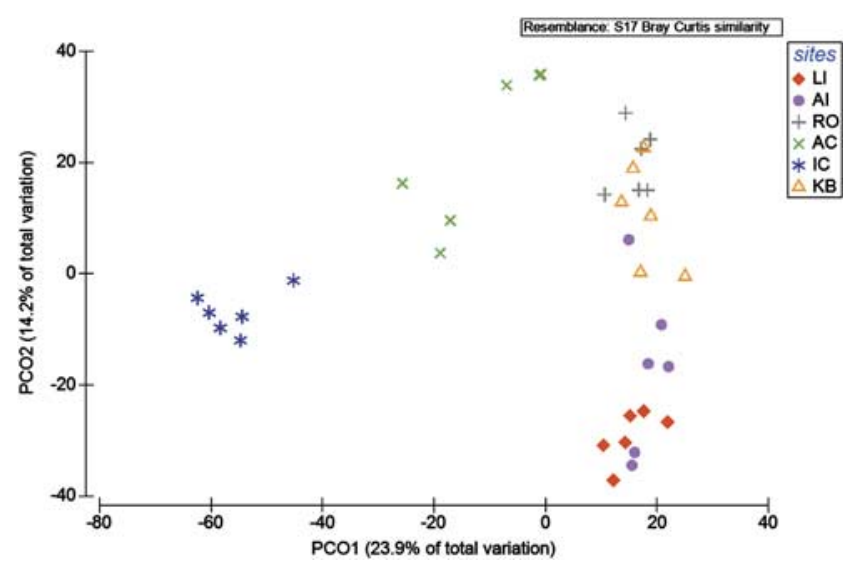

Fig. 3. Principal co-ordinate ordination $(\mathrm{PCO})$ of the bacterial community patterns based on proportional abundance of T-RFs. The PCO of the absence/presence of terminal restriction fragments (T-RFs) were very similar and are not shown.

T-RFs but varying proportional peak height, while those from IC showed the opposite (varied in peak number but the proportion of each peak is relatively more consistent).

The largest proportion of T-RFs were site specific $(\sim 31 \%)$ (i.e. found exclusively at one site and not at other locations) while only $\sim 3 \%$ of the T-RFs were detected in at least one replicate from all sites. Although the absence of "common" T-RFs might be due to the fact that the PCR based analyses were only capable of revealing numerically abundant species, this shows that the dominant bacterial species from the six sites were highly variable.

With such low overlap of T-RFs, it is perhaps unsurprising that both the PERMANOVA calculated using absence/ presence binary data and proportional abundance data suggested that each location harboured significantly different $(P<0.01)$ bacterial membership (occurrence of $\mathrm{T}-\mathrm{RF}$ peaks) and composition (relative abundance of T-RF peaks). In order to illustrate the relationship between the sampling sites, the soil bacterial assemblage patterns were examined using the PCO of the Jaccard similarity matrix (binary data) and Bray-Curtis similarity matrix (proportional abundance data). The two ordination plots showed similar results, where the samples from Ryder Bay were generally clustered on the PCO1-axis while AC encompassed bacterial assemblages intermediate to IC and Ryder Bay (Fig. 3). This is supported by a higher pairwise PERMANOVA average similarity between the four islands in Ryder Bay, in comparison with $\mathrm{AC}$ and IC (Table S2, www.journals.cambridge.org/jid_ANS). These distribution patterns were not linked with the geographical distances between study locations, as no significant relationship was detected when comparing the Jaccard and Bray-Curtis similarity matrices with the geographical distances using a Mantel test based on Spearman rank correlation.

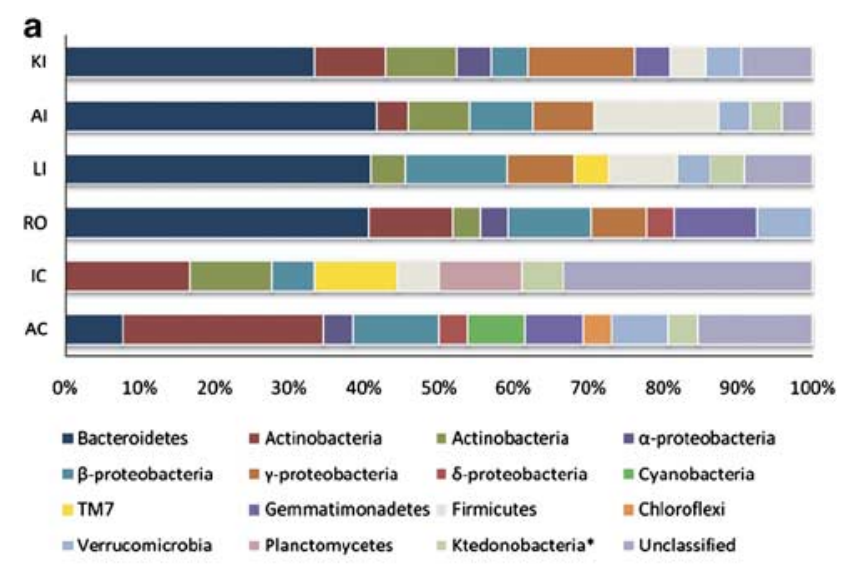

b

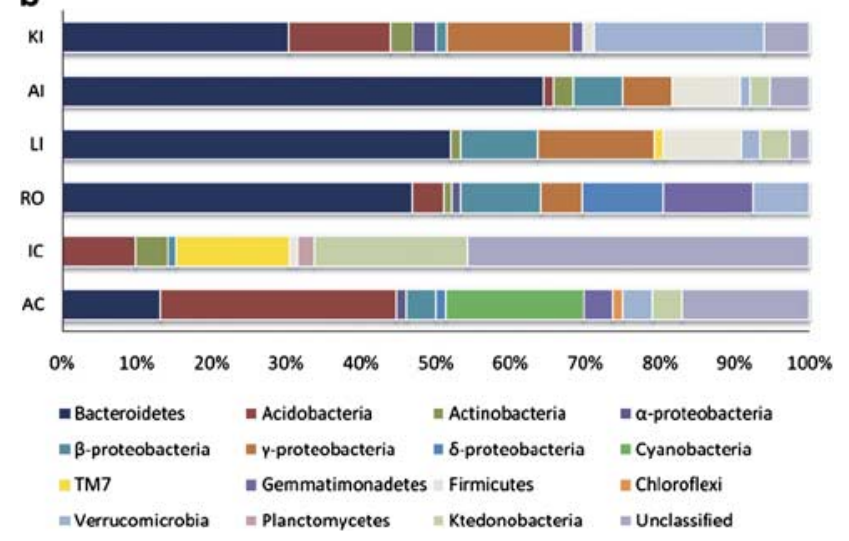

Fig. 4. Taxonomic composition of the clone libraries obtained. a. Composition based on the number of unique operational taxonomic units (OTUs). b. Composition based on the number of clones for each OTU.

Diversity inferred from T-RFLP needs to be interpreted with care. Problems such as the presence of background noise signal, inaccurate T-RF alignment, and varying DNA concentration might result in over- or underestimation of the true diversity. Additionally, the T-RFLP profiles obtained are known to be highly sensitive to the primer and restriction enzymes used (Liu et al. 1997, Schütte et al. 2008). To increase the robustness of our analysis, we adopted a strict filter to remove any background signal. We also adopted a clustering-based statistical approach (Smith et al. 2005) instead of nearest integer rounding to align and to estimate the size of the T-RFs. Further, the T-RFLP community composition was calculated using proportional peak height (raw peak height over total peak height) instead of raw peak height alone, to account for the differences in the DNA concentration of each sample.

In general, our data highlight the importance of local scale soil heterogeneity in structuring soil bacterial communities. For example, several previous studies have shown that the Antarctic soil bacterial community structure and soil development were closely related to 
local micro-environmental (e.g. altitude, slope, presence of vegetation, distance from sea, etc.) and chemical characteristics (e.g. water, carbon, nitrogen, $\mathrm{pH}$, etc.) (Yergeau et al. 2007, Cannone et al. 2008a, Chong et al. 2010).

\section{Bacterial community composition from cloning}

Overall, 120 unique OTUs spanning 16 different taxa (including 'unclassified' and the class Ktedonobacteria whose taxa are insertae sedis) were retrieved (Fig. $4 \mathrm{a} \& \mathrm{~b}$ ). The rarefaction curve for each clone library is given in Fig. S1 (www.journals.cambridge.org/jid_ANS), and the estimated total coverage ranged from $83-91 \%$. Based on the rarefaction curves, highest and lowest diversity was observed at $\mathrm{KB}$ and IC respectively, while similar OTU diversity was detected from the remaining sites. In addition, diversity estimated using the Chaol estimator suggested highest OTU diversity in KB (101.8), followed by AC (82.0), AI (73.8), LI (60.3), RO (41.7) and IC (35.6). The low diversity of IC corroborated the pattern observed using T-RFLP analysis.

All locations from Ryder Bay were dominated by Bacteriodetes, including Cyclobacteriaceae, Chitinophagaceae, Cytophagaceae, Flavobacteriaceae, Saprospiraceae and Sphingobacteriaceae. Together, these families accounted for $33-41 \%$ of the unique OTUs, or $30-64 \%$ of the total retrieved clones when considering repeated sequences (Fig. $4 \mathrm{a} \& \mathrm{~b}$ ).

Bacteroidetes have also been found to comprise a high proportion of the retrieved sequences in clone libraries and DGGE profiles in other studies - for instance, on Signy Island (Maritime Antarctic), Windmill Islands (East Antarctica), Bull Pass and Marble Point (northern Victoria Land), and in soil collected below a dead seal corpse on Cape Evans, (McMurdo Dry Valleys) (Shravage et al. 2007, Aislabie et al. 2008, 2009, Chong et al. 2009a, 2009b).

In comparison with Ryder Bay, Reptile Ridge sites generated a lower percentage of Bacteroidetes sequences, but harboured a higher proportion of Acidobacteria and unclassified bacteria. The IC flora in particular was predominantly composed of unclassified bacteria $(32 \%$ of the unique OTUs, and $46 \%$ inclusive of the repeated sequences) when compared to all other studied sites. The low occurrence of Bacteroidetes and high occurrence of Acidobacteria in nutrient poor environments such as Reptile Ridge are consistent with findings from Fierer et al. (2007) that the former are r-strategists which show higher relative abundance in nutrient rich environments while the latter are $\mathrm{K}$-strategists adapted to low nutrient ecosystems.

Furthermore, Planctomycetes, Cyanobacteria and Chloroflexi were only detected in Reptile Ridge samples. The former was restricted to IC while two representatives of the latter were found only at AC. The absence or low occurrence (i.e. below detection limit) of Cyanobacteria and Chloroflexi in IC was unexpected as this site does not receive direct external nutrient input from animals or humans except from melting snow. Therefore, primary producers are believed to have a major role in maintaining a stable soil community in this environment. A possible explanation for such low occurrence of Cyanobacteria and Chloroflexi might be that they are more prevalent in lithic environments (i.e. endolith and hypolith - not covered in this study) as seen in other arid and cold terrestrial ecosystems such as the McMurdo Dry Valleys (Pointing et al. 2010). Overall, the clone library analysis suggested that the sites were similar to soils from other parts of the Antarctic Peninsula based on clone library analysis.

Although it is difficult to ascertain the origin of the clones based on sequence information alone, previous studies have shown that it is possible to relate the putative habitat of the clones by comparing to the closest match of the sequences using the GenBank database (Zwart et al. 2002). Using a similar approach, by comparing the OTUs obtained in each site with the top five hits of the closest representatives from GenBank (all of which show $>97 \%$ homology; Table S3, www.journals.cambridge.org/jid_ANS), we found that a proportion of the retrieved clones from $\mathrm{LI}, \mathrm{KB}$ and $\mathrm{AI}$ $(\sim 30-43 \%)$ might be of marine origin. The association of the marine sequences in LI and $\mathrm{KB}$ is consistent with the two sites being strongly influenced by sea spray (high $\mathrm{EC} / \% \mathrm{NaCl}$ ) and marine vertebrate activities. Nevertheless, it is perhaps less expected that the AI samples were also dominated by marine bacteria, as the soil from AI generally showed lower conductivity (low $\% \mathrm{NaCl}$ ). A possible explanation is that the marine associated bacteria may be transferred to the soil via passive dispersal by the large skua population in this vicinity. Overall, our findings suggest that the ocean might be an important source of bacterial propagules to these coastal terrestrial environments. This is consistent with marine-associated sequences being wellrepresented in Antarctic aerobiological samples (Pearce et al. 2009). In addition, marine-derived nutrients are one of the major sources of external nutrient input to these terrestrial ecosystems (Bokhorst et al. 2007). In contrast, $\mathrm{RO}, \mathrm{IC}$ and AC were less impacted by marine influences, as these three sites showed less than $17 \%$ of marine associated clones in their respective clone libraries. Interestingly, the differences in community pattern (Fig. $3 a$ \& b) and phylogenetic composition (Fig. $4 \mathrm{a} \&$ b) mirrored the differences in the degree of marine and vertebrate influences (with the exception of RO, IC, and AC showing disparate bacterial community patterns and composition as opposed to $\mathrm{AI}, \mathrm{LI}$, and $\mathrm{KB}$ ), suggesting interaction between the bacterial community composition and varying levels of marine and vertebrate influences.

\section{Correlation of environmental variables with bacterial community patterns}

High local-scale variability in environmental parameters is generally a common feature of Antarctic soil (Chown \& Convey 2007). This includes regions such as the Dry 
Valleys that receive little external influence from plants and vertebrates (Cary et al. 2010). Therefore, it is perhaps expected that the measured variables show a certain extent of co-variation. Indeed, the co-variation of environmental parameters had been acknowledged by previous studies in other Antarctic environments (Aislabie et al. 2008, Cannone et al. 2008b). In this study, the measured parameters generally showed moderate to low correlation to each other (between each variable, $>75 \%$ or $22 / 28$ show Pearson $R$ lower than 0.7 ). Using the BEST routine, we were able to identify the combination of measured parameters that showed the highest explanatory value to the pattern detected in the T-RFLP analyses. This analysis suggests that the absence/presence of T-RFs was best explained by the heterogeneity in soil $\mathrm{pH}$ and altitude $(\rho=0.526, P=0.001)$, while the differences in the proportional abundance of T-RF peaks were strongly related to the variation in soil $\mathrm{pH}$, lead content and altitude $(\rho=0.609, P=0.001)$.

It is perhaps surprising that water availability might be relatively unimportant to the soil bacteria communities of Reptile Ridge and Ryder Bay, as differences in water availability have been shown to be the main contributor to variability in soil eukaryotic community composition in Antarctica (i.e. algae, fungi, nematodes and arthropods) (Convey et al. 2003, Fell et al. 2006, Bridge \& Newsham 2009). This potentially suggested that the soil bacterial community in the soils of Reptile Ridge and Ryder Bay are more resistant to the fluctuation in water content than those of other drier environments in Antarctica (e.g. Aislabie et al. 2008). The lack of correlation between the measured water content and the soil bacterial community could also be due to the limitation of gravimetric water content in reflecting true bioavailability of water, as this is easily influenced by the temperature and weather conditions during the time of sampling (Gold \& Bliss 1995, Kursar et al. 2005). Further, liquid water may be present periodically in the soil through interaction between the dry surface air and subsurface permafrost layer (Cary et al. 2010). Nonetheless, our results indicating that water might have a low influence on the soil bacterial composition are comparable with Newsham et al. (2010) who showed that soils with contrasting levels of moisture content in Mars Oasis, Antarctic Peninsula can harbour taxonomically similar bacterial communities.

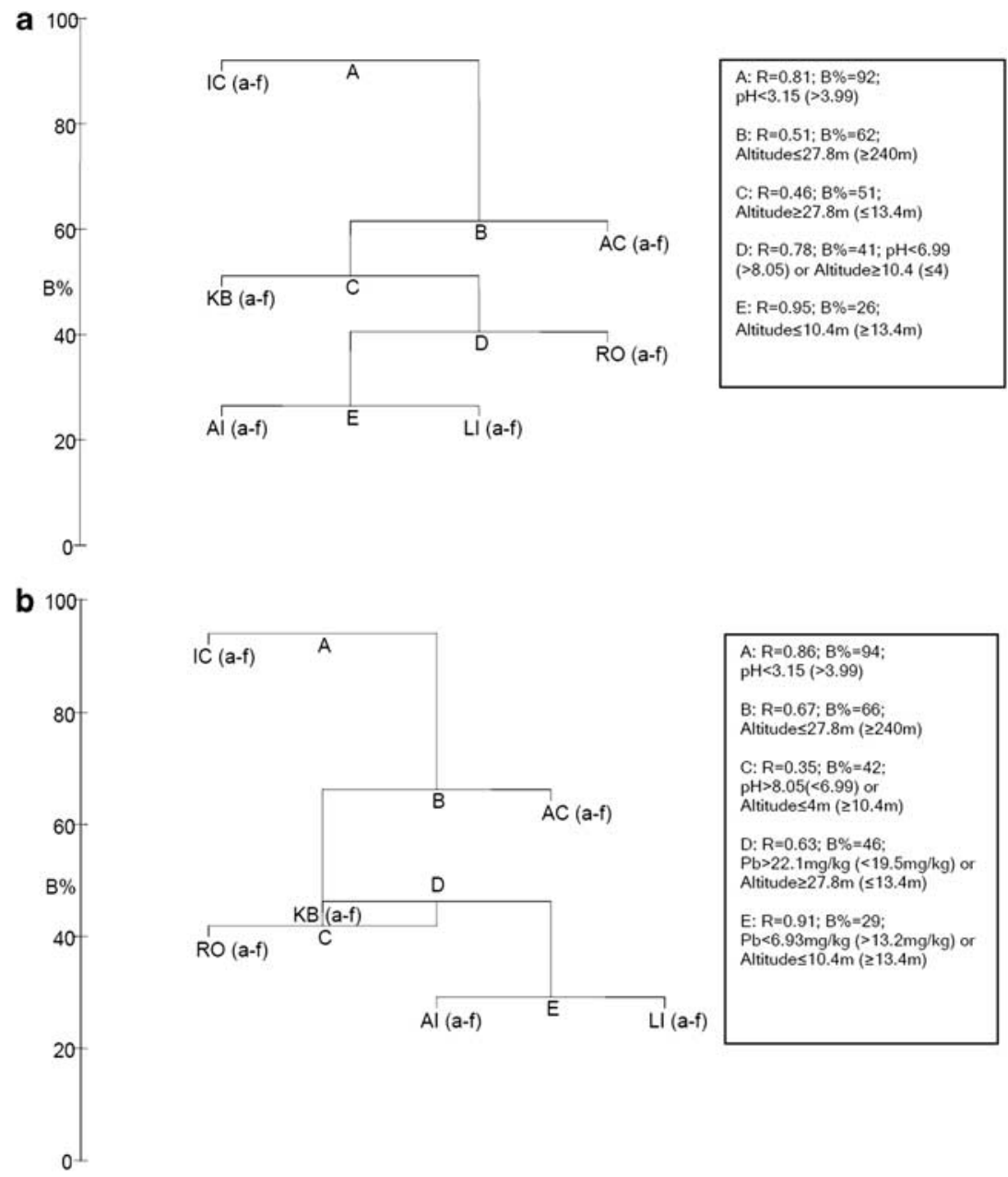

Fig. 5. LINKTREE clustering inferred from a. absence/presence of T-RFs, and b. proportional abundance of each of the T-RFs. For each binary separation, environmental factor(s) accounting for the clustering to the left are listed first, followed by the factor(s) for the clustering to the right (in parenthesis). The $\mathrm{B} \%$ indicates the similarity/ dissimilarity between grouping: The higher the $\mathrm{B} \%$, the greater the dissimilarity between cluster. Note: only branching nodes which showed $P<0.05$ in the SIMPROF test (999 resampling) were shown. 
The division of the studied locations in relation to the BEST identified parameters was further examined using LINKTREE analysis. Figure $5 \mathrm{a} \& \mathrm{~b}$ suggests that the main factor contributing to the demarcation of IC from the remaining samples was the difference in $\mathrm{pH}$ value. Variation in soil $\mathrm{pH}$ can result in deviation in bacterial metabolic response (Bååth 1996). The relatively strongly acidic soil in IC compared to the other studied locations might have exerted a selection pressure preferentially selecting for bacterial taxa such as Ktedonobacteria and Planctomycetes that can tolerate high acid stress.

Variation in position (altitude) was also identified as a means to separate the underlying soil bacterial community patterns (i.e. AC vs KB and LI). This is consistent with previous studies suggesting that the heterogeneity in soil bacterial activities and composition were dependent on differences in altitude (Bryant et al. 2008, Margesin et al. 2009, Cowan et al. 2011). Differences in altitude are also likely to co-vary with the degree of marine influence, thus resulting in the separation of high and low lying locations. Generally, all sites from Ryder Bay were grouped in a cluster with lower $\mathrm{B} \%$ (the higher the $\mathrm{B} \%$, the greater the dissimilarity between clusters) suggesting relatively homogeneous bacterial communities between the four islands in comparison to Reptile Ridge. However, they can be further split according to the variation in location, $\mathrm{pH}$ and/or lead content. Soil with higher lead content is expected to exert a higher selective pressure towards bacterial taxa with higher lead tolerance. This is likely to result in differences between bacterial communities from soil with varying levels of lead content (Konopka et al. 1999).

In conclusion, a statistical comparison between bacterial community structure and selected environmental parameters suggested that $\mathrm{pH}$ and position (altitude) were most strongly correlated with T-RFLP patterns while no correlation was found with the distance between the study sites. This pattern is in agreement with the differences in the taxonomic composition of the clone libraries obtained, where a higher proportion of Bacteroidetes was detected in the soil from the low lying islands around Ryder Bay but higher prevalence of Acidobacteria and unclassified bacteria was found in the acidic and elevated soil from Reptile Ridge. Further, we suggest that the altitude might also co-vary with the level of marine associated influences such as sea spray and presence of vertebrate influence. In general, our results that both soil $\mathrm{pH}$ and position might be the key environmental factors in Ryder Bay and Reptile Ridge are in agreement with other reports from the Arctic (Margesin et al. 2009, Chu et al. 2010) and Antarctic (Chong et al. 2009a, 2010, Cowan et al. 2011). Taken together, these factors might restrict the type of bacteria that can colonize each specific habitat. Clearly, molecular assessment of 16S rDNA might not fully reflect the viable members in soil microbial communities. Therefore, a more robust field sampling design and further study on the physiological response of the soil bacterial community to variation in soil $\mathrm{pH}$, altitude and marine associated factors is very much warranted.

\section{Acknowledgements}

This project was funded by the Malaysian Antarctic Research Programme (MARP), and the British Antarctic Survey (BAS) provided logistic support and field training. We thank Matt von Tersh for assistance in sample collection. This study contributes to the BAS 'Polar Science for Planet Earth' and SCAR 'Evolution and Biodiversity in Antarctica' research programmes. The constructive comments of the reviewers are also gratefully acknowledged.

\section{Supplemental material}

Three supplemental tables and one figure will be found at http://dx.doi.org/10.1017/S0954102012000028.

\section{References}

Aislabie, J.M., Jordan, S. \& Barker, G.M. 2008. Relation between soil classification and bacterial diversity in soils of the Ross Sea region, Antarctica. Geoderma, 144, 9-20.

Aislabie, J., Jordan, S., Ayton, J., Klassen, J.L., Barker, G.M. \& Turner, S. 2009. Bacterial diversity associated with ornithogenic soil of the Ross Sea region, Antarctica. Canadian Journal of Microbiology, 55, 21-36.

Anderson, M.J., Gorley, R.N. \& Clarke, K.R. 2008. PERMANOVA+ for PRIMER: guide to software and statistical methods. Plymouth: PRIMER-E, 214 pp.

Ashelford, K.E., Chuzhanova, N.A., Fry, J.C., Jones, A.J. \& Weightman, A.J. 2005. At least 1 in 20 16S rRNA sequence records currently held in public repositories is estimated to contain substantial anomalies. Applied and Environmental Microbiology, 71, 7724-7736.

Ashelford, K.E., Chuzhanova, N.A., Fry, J.C., Jones, A.J. \& Weightman, A.J. 2006. New screening software shows that most recent large $16 \mathrm{~S}$ rRNA gene clone libraries contain chimeras. Applied and Environmental Microbiology, 72, 5734-5741.

BÅÅTH, E. 1996. Adaptation of soil bacterial communities to prevailing $\mathrm{pH}$ in different soils. FEMS Microbiology Ecology, 19, 227-237.

Boknorst, S., Huiskes, A., Convey, P. \& Aerts, R. 2007. External nutrient inputs into terrestrial ecosystems of the Falkland Islands and the Maritime Antarctic region. Polar Biology, 30, 1315-1321.

Bridge, P.D. \& Newsham, K.K. 2009. Soil fungal community composition at Mars Oasis, a southern Maritime Antarctic site, assessed by PCR amplification and cloning. Fungal Ecology, 2, 66-74.

Bryant, J.A., Lamanna, C., Morlon, H., Kerkhoff, A.J., Enquist, B.J. \& Green, J.L. 2008. Colloquium paper: microbes on mountainsides: contrasting elevational patterns of bacterial and plant diversity. The Proceedings of the National Academy of Sciences the United States of America, 105, 11 505-11511.

Cannone, N., Diolaiuti, G., Guglielmin, M. \& Smiraglia, C. $2008 \mathrm{a}$. Accelerating climate change impacts on alpine glacier forefield ecosystems in the European Alps. Ecological Applications, 18, 637-648.

Cannone, N., Wagner, D., Hubberten, H.W. \& Guglielmin, M. 2008b. Biotic and abiotic factors influencing soil properties across a latitudinal gradient in Victoria Land, Antarctica. Geoderma, 144, 50-65.

Cary, S.C., McDonald, I.R., Barrett, J.E. \& Cowan, D.A. 2010. On the rocks: the microbiology of Antarctic Dry Valley soils. Nature Reviews Microbiology, 8, 129-138. 
Chong, C.W., Tan, G.Y.A., Wong, R.C.S., Riddle, M.J. \& Tan, I.K.P. 2009b. DGGE fingerprinting of bacteria in soils from eight ecologically different sites around Casey Station, Antarctica. Polar Biology, 32, 853-860.

Chong, C.W., Dunn, M.J., Convey, P., Tan, G.Y.A., Wong, R.C.S. \& Tan, I.K.P. 2009a. Environmental influences on bacterial diversity of soils on Signy Island, Maritime Antarctic. Polar Biology, 32, 1571-1582.

Chong, C.W., Pearce, D.A., Convey, P., Tan, G.Y.A., Wong, R.C.S. \& TAN, I.K.P. 2010. High levels of spatial heterogeneity in the biodiversity of soil prokaryotes on Signy Island, Antarctica. Soil Biology and Biochemistry, 42, 601-610.

Chown, S.L. \& Convey, P. 2007. Spatial and temporal variability across life's hierarchies in the terrestrial Antarctic. Philosophical Transactions of the Royal Society, B362, 2307-2331.

Chu, H., Fierer, N., Lauber, C.L., Caporaso, J.G., Knight, R. \& Grogan, P. 2010. Soil bacterial diversity in the Arctic is not fundamentally different from that found in other biomes. Environmental Microbiology, 12, 2998-3006.

Clarke, K.R., Somerfield, P.J. \& Gorley, R.N. 2008. Testing of null hypotheses in exploratory community analyses: similarity profiles and biota-environment linkage. Journal of Experimental Marine Biology and Ecology, 366, 56-69.

Convey, P. 2003. Maritime Antarctic climate change: signals from terrestrial biology. Antarctic Research Series, 79, 145-158.

Convey, P. \& Sмith, R.I.L. 1997. The terrestrial arthropod fauna and its habitats in northern Marguerite Bay and Alexander Island, Maritime Antarctic. Antarctic Science, 9, 12-26.

Convey, P., Block, W. \& Peat, H.J. 2003. Soil arthropods as indicators of water stress in Antarctic terrestrial habitats? Global Change Biology, 9, 1718-1730.

Cowan, D., Pointing, S., Stevens, M., Cary, S.C., Stomeo, F. \& Tuffin, I. 2011. Distribution and abiotic influences on hypolithic microbial communities in an Antarctic Dry Valley. Polar Biology, 34, 307-311.

Culman, S.W., Bukowski, R., Gauch, H.G., Cadillo-Quiroz, H. \& BuCKLEY, D.H. 2009. T-REX: software for the processing and analysis of T-RFLP data. BMC Bioinformatics, 10, 171.

Fell, J.W., Scorzetti, G., Connell, L. \& Craig, S. 2006. Biodiversity of micro-eukaryotes in Antarctic Dry Valley soils with $<5 \%$ soil moisture. Soil Biology and Biochemistry, 38, 3107-3119.

Fierer, N., BRADFORD, M.A. \& JACKSON, R.B. 2007. Toward an ecological classification of soil bacteria. Ecology, 88, 1354-1364.

Foong, C.P., Wong Vui Ling, C.M. \& GonzÁlez, M. 2010. Metagenomic analyses of the dominant bacterial community in the Fildes Peninsula, King George Island (South Shetland Islands). Polar Science, 4, 263-273.

Ganzert, L., Lipski, A., HubBERTEn, H.W. \& Wagner, D. 2011. The impact of different soil parameters on the community structure of dominant bacteria from nine different soils located on Livingston Island, South Shetland Archipelago, Antarctica. FEMS Microbiology Ecology, 76, 476-491.

GoLd, W.G. \& Buiss, L.C. 1995. Water limitations and plant community development in a polar desert. Ecology, 76, 1558-1568.

Griffiths, C.J. \& OGLethorpe, R.D.J. 1998. The stratigraphy and geochronology of Adelaide Island. Antarctic Science, 10, 462-475.

Hartman, W.H., Richardson, C.J., Vilgalys, R. \& Bruland, G.L. 2008. Environmental and anthropogenic controls over bacterial communities in wetland soils. Proceedings of the National Academy of Sciences of the United States of America, 105, 17 842-17847.

Konopka, A., Zakharova, T., Bischoff, M., Oliver, L., Nakatsu, C. \& TuRCO, R.F. 1999. Microbial biomass and activity in lead-contaminated soil. Applied and Environmental Microbiology, 65, 2256-2259.

Kursar, T.A., Engelbrecht, B.M.J. \& Tyree, M.T. 2005. A comparison of methods for determining soil water availability in two sites in Panama with similar rainfall but distinct tree communities. Journal of Tropical Ecology, 21, 297-305.
Liu, W.T., Marsh, T.L., Cheng, H. \& Forney, L.J. 1997. Characterization of microbial diversity by determining terminal restriction fragment length polymorphisms of genes encoding 16S rRNA. Applied and Environmental Microbiology, 63, 4516-4522.

Männistö, M.K., Tıirola, M. \& Häggblom, M.M. 2007. Bacterial communities in Arctic fjelds of Finnish Lapland are stable but highly pH-dependent. FEMS Microbiology Ecology, 59, 452-465.

Margesin, R., Jud, M., Tscherko, D. \& Schinner, F. 2009. Microbial communities and activities in alpine and subalpine soils. FEMS Microbiology Ecology, 67, 208-218.

Newsham, K.K., Pearce, D.A. \& Bridge, P.D. 2010. Minimal influence of water and nutrient content on the bacterial community composition of a Maritime Antarctic soil. Microbiological Research, 165, 523-530.

NygåRD, T., Lie, E., Røv, N. \& Steinnes, E. 2001. Metal dynamics in an Antarctic food chain. Marine Pollution Bulletin, 42, 598-602.

Pearce, D.A., Bridge, P.D., Hughes, K.A., Sattler, B., Psenner, R. \& Russell, N.J. 2009. Microorganisms in the atmosphere over Antarctica. FEMS Microbiology Ecology, 69, 143-157.

Pointing, S.B., Chan, Y., Lacap, D.C., Lau, M.C.Y., Jurgens, J.A. \& FARRELL, R.L. 2010. Highly specialized microbial diversity in hyper-arid polar desert. The Proceedings of the National Academy of Sciences of the United States of America, 107, 1254-1254.

Santos, I.R., Silva-Filho, E.V., Schaefer, C.E.G.R., Albuquerque-Filho, M.R. \& CAmpos, L.S. 2005. Heavy metal contamination in coastal sediments and soils near the Brazilian Antarctic Station, King George Island. Marine Pollution Bulletin, 50, 185-194.

Schloss, P.D., Westcott, S.L., Ryabin, T., Hall, J.R., Hartmann, M., Hollister, E.B., Lesniewski, R.A., OAkley, B.B., Parks, D.H., Robinson, C.J., Sahl, J.W., Stres, B., Thallinger, G.G., van Horn, D.J. \& WeBER, C.F. 2009. Introducing mothur: open-source, platformindependent, community-supported software for describing and comparing microbial communities. Applied and Environmental Microbiology, 75, 7537-7541.

Schütte, U., Abdo, Z., Bent, S., Shyu, C., Williams, C., Pierson, J. \& ForNey, L. 2008. Advances in the use of terminal restriction fragment length polymorphism (T-RFLP) analysis of 16S rRNA genes to characterize microbial communities. Applied Microbiology and Biotechnology, 80, 365-380.

Seymour, F.A., Crittenden, P.D., Wirtz, N., Øvstedal, D.O., Dyer, P.S. \& LumBSCH, H.T. 2007. Phylogenetic and morphological analysis of Antarctic lichen-forming Usnea species in the group Neuropogon. Antarctic Science, 19, 71-82.

Shravage, B.V., Dayananda, K.M., Patole, M.S. \& Shouche, Y.S. 2007. Molecular microbial diversity of a soil sample and detection of ammonia oxidizers from Cape Evans, McMurdo Dry Valley, Antarctica. Microbiological Research, 162, 15-25.

Smith, C.J., Danilowicz, B.S., Clear, A.K., Costello, F.J., Wilson, B. \& MeIJer, W.G. 2005. T-Align, a web-based tool for comparison of multiple terminal restriction fragment length polymorphism profiles. FEMS Microbiology Ecology, 54, 375-380.

Teixeira, L.C.R.S., Peixoto, R.S., Cury, J.C., Sul, W.J., Pellizari, V.H., Tiedje, J. \& Rosado, A.S. 2010. Bacterial diversity in rhizosphere soil from Antarctic vascular plants of Admiralty Bay, Maritime Antarctica. The ISME Journal, 4, 989-1001.

Tindall, B.J. 2004. Prokaryotic diversity in the Antarctic: the tip of the iceberg. Microbial Ecology, 47, 271-283.

Yergeau, E., Newhham, K.K., Pearce, D.A. \& Kowalchuk, G.A. 2007. Patterns of bacterial diversity across a range of Antarctic terrestrial habitats. Environmental Microbiology, 9, 2670-2682.

Zwart, G., Crump, B.C., Agterveld, M.P.K.-V., Hagen, F. \& Han, S.-K. 2002. Typical freshwater bacteria: an analysis of available 16S rRNA gene sequences from plankton of lakes and rivers. Aquatic Microbial Ecology, 28, 141-155. 